\title{
RESPON MORFOGENESIS EKSPLAN PUCUK ANGGREK TEBU (Grammatophylum speciosum Blume) SECARA IN VITRO TERHADAP BEBERAPA KONSENTRASI KINETIN
}

\author{
Ellok Dwi Sulichantini ${ }^{1}$, Susylowati ${ }^{1}$, Ariya Ramadhan ${ }^{1}$ \\ ${ }^{1}$ Jurusan Agroekoteknologi Fakultas Pertanian Universitas Mulawarman \\ Jl. Pasir Balengkong Kampus Gunung Kelua Samarinda, 75123 \\ Kalimantan Timur, Indonesia \\ E-Mail: ellokds@gmail.com
}

\begin{abstract}
ABSTRAK
Respon Morfogenesis Eksplan Pucuk Anggrek Tebu (Grammatophylum speciosum Blume) Secara In Vitro Terhadap Beberapa Konsentrasi Kinetin. Anggrek tebu (Grammatophyllum speciosum Blume) dikenal sebagai jenis anggrek raksasa, anggrek dewasa dapat memiliki berat 1 ton, malai dapat tumbuh hingga 2,5-3 meter dengan diameter sekitar 1,5-2 cm. Setiap malai memiliki belasan, bahkan mencapai seratus kuncup bunga, masing-masing berdiameter sekitar satu $10 \mathrm{~cm}$. Anggrek tebu merupakan salah satu jenis tanaman yang dilindungi karena keberadaannya yang semakin langka sehingga membutuhkan teknik perbanyakan secara in vitro untuk menunjang kelangsungan hidupnya.

Untuk meningkatkan pertumbuhan Grammatophyllum speciosum Blume pada pucuk tunas ditanam pada media MS dengan variasi konsentrasi kinetin $(0,1,2,3$, dan 4 mg L-1) dengan 5 kali ulangan. Ujung pucuk dari kultur in vitro dengan panjang sekitar $1 \mathrm{~cm}$ digunakan sebagai eksplan. Pengamatan dilakukan selama 8 minggu setelah inokulasi.

Hasil penelitian menunjukkan bahwa ujung pucuk eksplan tumbuh dengan baik pada media dasar MS. Penambahan kinetin ke dalam media meningkatkan laju pertumbuhan kultur. Peningkatan konsentrasi kinetin cenderung meningkatkan pertumbuhan. Konsentrasi terbaik untuk induksi pertumbuhan pada tinggi tanaman, diameter batang, panjang daun dan panjang akar adalah 2 mg.L-1 kinetin, sedangkan 3 mg.L-1 kinetin memberikan respon terbaik pada jumlah daun dan $4 \mathrm{mg}$. Konsentrasi L-1 kinetin terbaik pada lebar daun dan jumlah akar.
\end{abstract}

Kata kunci : Anggrek, Grammatophyllum speciosum, In Vitro, Kinetin.

\begin{abstract}
Morphogenesis Response of Cane Orchid Shoots (Grammatophylum speciosum Blume) by In Vitro to Several Kinetin Concentrations. Sugarcane orchid (Grammatophyllum speciosum Blume) are known as a type of giant orchid, adult orchids can weigh 1 ton, panicle can grow up to $2.5-3$ meters with a diameter of about 1.5-2 cm. Each panicle has dozens, even reaching one hundred flower buds, each with a diameter of about one $10 \mathrm{~cm}$. Sugarcane orchids are a type of plant that is protected because its existence is increasingly scarce so that it needs in vitro propagation techniques to support its survival.

To improve the growth of Grammatophyllum speciosum Blume in vitro shoot tip was growing on MS medium with varying concentration of kinetin $\left(0,1,2,3\right.$, and $\left.4 \mathrm{mg} \mathrm{L}^{-1}\right)$ with 5 replications. Shoot tip from in vitro culture around $1 \mathrm{~cm}$ lengt was used as explants. Observations carried out for 8 weeks after inoculation.

The results showed that shoot explants tip growth well in MS basic medium. The addition of kinetin to the medium, increases growth rate of culture. Increasing the concentration of kinetin tends to increase the growth. The best concentration for growth induction on plant height, stem diameter, leaves length and length of roots was $2 \mathrm{mg} . \mathrm{L}^{-1}$ kinetin, On the other hand $3 \mathrm{mg} . \mathrm{L}^{-1}$ kinetin gave best response on number of leaves and $4 \mathrm{mg} . \mathrm{L}^{-1}$ kinetin was the best concentration on leaves width and number of roots.
\end{abstract}

Key words : Grammatophyllum speciosum, In Vitro, Kineti, Orchid. 


\section{PENDAHULUAN}

Anggrek merupakan jenis tanaman dengan bunga yang sangat indah, selain berperan sebagai tanaman hias beberapa jenis anggrek juga bermanfaat sebagai obat, dan minyak wangi. Famili orchidaceae memiliki jumlah genus dan spesies yang sangat besar, sehingga variasi bunganya juga sangat besar. Variasi bunga dapat dilihat dari warna bunga, ukuran bunga, bentuk bunga, ketebalan bunga, aroma bunga, jumlah kuntum bunga pertangkai, panjang tangkai bunga, dan letak bunga dalam tangkai.

Anggrek tebu (Grammatophyllum speciosum) sampai saat ini dikenal sebagai anggrek yang terbesar. Grammatophyllum merupakan marga anggrek tropis dan memiliki 12 jenis yang tersebar di dunia. G. speciosum disebut juga sebagai anggrek tebu, ratu anggrek atau tiger orchid. Anggrek tebu tersebar luas di seluruh Asia Tenggara seperti Myanmar, Thailand, Laos, Vietnam, Malaysia, Indonesia, Papua Nuginea dan Kepulauan Solomon. Di Indonesia anggrek tebu tersebar di Sumatera, Kalimantan, Jawa, Sulawesi, Maluku dan Papua. Anggrek tebu tumbuh secara epifit pada pohon-pohon besar di daerah dataran rendah yang beriklim tropis. Anggrek tebu memerlukan sinar matahari langsung (Anonim, 2015; O'Byrne 1994; Salifah, et al. 2011; Yukawa, et al. 2013).

Satu rumpun anggrek dewasa dapat mencapai berat 1 ton, dengan panjang mencapai 3 meter. Bunga anggrek tebu berwarna kuning dengan bintik-bintik coklat, merah, dan merah kehitaman. Tangkai bunga keluar diantara dua ketiak daun. Berdasarkan tipe pertumbuhannya, anggrek tebu termasuk dalam tipe monopodial yaitu mempunyai pertumbuhan tidak terbatas,terus tumbuh ke atas. Anggrek tebu tidak mempunyai umbi, bentuk batangnya ramping. Malai dapat mencapai tinggi 2,5-3 meter dengan diameter 1,5-2 meter. Setiap malai dapat memiliki ratusan kuntum bunga, masingmasing bunga mempunyai diameter sekitar $10 \mathrm{~cm}$. Bunga anggrek tebu yang dipotong dari batangnya mampu bertahan selama 2 bulan (Herawati, 2013).

Anggrek tebu termasuk jenis anggrek yang banyak diminati masyarakat sehingga keberadaannya di alam menjadi terancam akibat pengambilan yang berlebihan. Langkanya keberadaan anggrek tebu di habitat aslinya dipengaruhi oleh berbagai faktor antara lain adalah adanya perubahan atau rusaknya habitat tumbuh akibat penebangan hutan dan alih guna lahan. Eksploitasi anggrek tebu di alam yang dilakukan secara terus menerus akan mengakibatkan kepunahan, sehingga perlu dilakukan kegiatan konservasi.

Menurut Irawati (2001), salah satu genus anggrek yang hampir punah yaitu Grammatophyllum. Grammatophyllum speciosum Blume masuk dalam Apendiks II CITES sejak tahun 2005 bersama dengan seluruh jenis anggrek, kecuali dari marga Pahiophedilum (CITES 2005). Menurut Anonim (1999), peraturan Pemerintah Republik Indonesia Nomor 7 Tahun 1999 tentang Pengawetan Jenis Tumbuhan dan Satwa menetapkan bahwa Grammatophyllum merupakan salah satu jenis anggrek yang dilindungi. Menurut Sabran dan Firmansyah (2015) tidak sedikit jenis anggrek Indonesia mulai terancam keberadaannya di habitat alaminya, termasuk jenis anggrek tebu. Selain itu banyak jenis anggrek yang penyebarannya terbatas diperkirakan sudah punah di tempat aslinya, oleh karena itu sebagai upaya pelestarian plasma nutfah tanaman anggrek perlu dilakukannya eksplorasi maupun karakterisasi. Aprilianti, (2018) menyatakan bahwa Pusat Konservasi Tumbuhan Kebun Raya-LIPI telah 
melaksanakan kegiatan konservasi anggrek Grammatophyllum speciosum melalui kegiatan eksplorasi di hutanhutan Indonesia dan juga pengembangan secara in vitro maupun ex vitro, termasuk pengembangan benih sintetik.

Perbanyakan anggrek secara konvensional secara vegetatif dapat dilakukan dengan stek batang, pemisahan rumpun, pemisahan pseudobuld, dan keiki (Gunawan, 2004). Perbanyakan secara generatif dengan menggunakan biji mengalami kesulitan karena biji-biji anggrek hasil penyerbukan alami tidak mempunyai cadangan makanan, sehingga tidak dapat berkecambah. Di alam perkecambahan bisa terjadi apabila ada asosiasi dengan mikoriza. Menurut Kumaria dan Tandon (2010), persentase keberhasilan perkecambahan biji di alam sangat rendah yaitu sekitar $1 \%$.

Teknik perbanyakan secara kultur jaringan termasuk salah satu cara untuk melestarikan keberadaan anggrek tebu sehingga terhindar dari kepunahan. Teknik perbanyakan secara kultur jaringan dapat dilakukan tanpa perlu adanya asosiasi dengan mikoriza, seperti yang telah ditunjukkan oleh Knudson pada tahun 1922 (Knudson, 1922). Teknik kultur jaringan merupakan solusi perbanyakan biji yang tidak mempunyai cadangan makanan seperti anggrek, karena teknik ini menggunakan media buatan yang kaya nutrisi.

Pradhan et al. (2016), menggunakan teknik kultur jaringan untuk melestarikan anggrek Cymbidium. Menurut Gunawan, (1992), Teknik kultur jaringan mempunyai kelebihan dapat menghasilkan bibit dalam jumlah banyak, dalam waktu cepat, dan bibit seragam, pengadaan bibit tidak tergantung musim, dan memerlukan ruang yang relatif kecil. Menurut, Zulkarnain (2009) bahwa manfaat utama dari aplikasi teknik in vitro adalah perbanyakan klon atau perbanyakan massal dari tanaman yang sifat genetiknya identik dengan induknya. Selain itu metode in vitro bermanfaat dalam beberapa hal khusus yaitu perbanyakan klon secara cepat, keseragaman genetik, kondisi aseptik, seleksi tanaman, lingkungan terkendali dan pelestarian plasma nutfah.

Media dalam kultur in vitro merupakan salah satu faktor penting penentu keberhasilan perbanyakan tanaman secara in vitro. Media tanam harus berisi semua zat yang diperlukan untuk menjamin kebutuhan eksplan. Komponen penyusun media tanam terdiri dari campuran garam mineral, unsur makro dan unsur mikro, sumber karbon, protein, vitamin,buffer, sukrosa sebagai sumber energy, asam amino dan hormon tumbuhan. Media tumbuh yang biasa digunakan untuk anggrek adalah media Vacin and Went (VW) dan Murashige dan Skoog (MS). Menurut Wetherell (1982), konsentrasi optimum dari unsur-unsur nutrisi untuk pertumbuhan berbeda-beda tergantung pada jenis tanaman dan tujuan kultur yang diinginkan.

Keberhasilan kultur in vitro juga ditentukan oleh zat pengatur tumbuh (ZPT) yang diberikan. Zat pengatur tumbuh yang banyak digunakan adalah golongan sitokinin dan auksin (Wattimena et al., 1992). Pemanfaatan sitokinin dan auksin pada teknik kultur jaringan dibutuhkan untuk memacu terbentuknya organ-organ. Sitokinin digunakan untuk memacu pembelahan sel, dimana ketika berinteraksi dengan auksin dalam konsentrasi yang tepat, maka akan tumbuh sel-sel meristem yang terus membelah dan berkembang membentuk organ. Sitokinin berfungsi untuk meregulasi pembelahan sel, memacu organogenesis, perkembangan kloroplas, menginduksi embriogenesis dan organogenesis (Salisburry dan Ross, 1995). Interaksi antara zat pengatur tumbuh yang ditambahkan atau eksogen 
dengan hormon yang diproduksi oleh sel secara endogen akan menentukan arah perkembangan suatu kultur. Perbandingan auksin yang tinggi sedangkan sitokinin yang rendah akan mendorong morfogenesis akar sebaliknya sitokinin dengan konsentrasi tinggi sedangkan auksin rendah akan mendorong pembentukan tunas (George dan Sherrington 1984). Menurut Zulkarnain (2009), tanpa menggunakan zat pengatur tumbuh maka akan sulit mencapai keberhasilan perbanyakan secara in vitro. Menurut Santoso dan Nursandi (2004), pemberian zat pengatur tumbuh yang melebihi konsentrasi yang diperlukan tanaman dapat menjadi penghambat pertumbuhan. Menurut George dan Sherrington (1984), rasio antara hormon sitokinin dan auksin yang diperlukan untuk meregenerasi suatu eksplan tidak mutlak sama pada tiap jenis tanaman. Penelitian dilaksanakan untuk mengetahui pengaruh konsentrasi kinetin terhadap morfogenesis eksplan anggrek tebu.

\section{METODA PENELITIAN}

\subsection{Tempat dan Waktu}

Penelitian dilaksanakan di Laboratorium Kultur Jaringan, Fakultas Pertanian, Universitas Mulawarman, pada bulan Desember 2018 sampai April 2019.

\subsection{Bahan dan Alat}

Alat-alat yang digunakan dalam penelitian ini adalah autoklaf, laminar air flow cabinet (LAFC), timbangan analitik, botol kultur, $\mathrm{pH}$ indikator, pisau, cawan petri, pipet, gelas ukur, erlenmeyer berbagai ukuran, tabung reaksi, bunsen, spayer, refrigerator dan rak inkubasi. Bahan-bahan yang digunakan dalam penelitian ini adalah pucuk steril anggrek tebu (Grammatophyllum speciosum blume) ukuran sekitar 1 $\mathrm{cm}$, dan zat pengatur tumbuh yang digunakan adalah kinetin. Bahanbahan lainnya yaitu $\mathrm{HCl}(1 \mathrm{~N})$ dan $\mathrm{NaOH}$ (1N) untuk mengatur $\mathrm{pH}$, alkohol $70 \%$ dan $90 \%$, serta plastik bening, karet, spirtus, akuades, gula, agar, masker, dan sarung tangan.

\subsection{Rancangan Penelitian}

Penelitian ini menggunakan Rancangan Acak Lengkap (RAL) faktor tunggal dengan ulangan sebanyak 5 kali. Faktor perlakuan yaitu konsentrasi Kinetin terdiri atas lima taraf, yaitu $\mathrm{k}_{0}=0 \mathrm{mg} \mathrm{L}^{-1}, \mathrm{k}_{1}=1$ $\mathrm{mg} \mathrm{L}^{-1}, \mathrm{k}_{2}=2 \mathrm{mg} \mathrm{L}^{-1}, \mathrm{k}_{3}=3 \mathrm{mg} \mathrm{L}^{-1}$, dan $\mathrm{k}_{4}=4 \mathrm{mg} \mathrm{L}^{-1}$. Media dasar yang digunakan adalah media Murashige dan Skoog (MS)

\subsection{Pengamatan}

Pengamatan dilakukan setiap minggu sampai umur 8 minggu setelah inokulasi (MSI). Variabel yang diamati dalam penelitian ini adalah pertambahan tinggi tanaman $(\mathrm{mm})$, pertambahan jumlah daun (buah), pertambahan lebar daun (mm), pertambahan panjang daun (mm), waktu muncul akar (his), jumlah akar (buah) dan panjang akar (mm)

\section{HASIL PENELITIAN DAN PEMBAHASAN}

Zat pengatur tumbuh tanaman berperan penting dalam mengontrol proses biologi dalam jaringan tanaman, mengatur kecepatan pertumbuhan dari masing-masing jaringan Aktivitas zat pengatur tumbuh di dalam pertumbuhan tergantung dari jenis, struktur kimia, konsentrasi, genotipe tanaman serta fase fisiologi tanaman (Satyavathi et al., 2004). Proses pertumbuhan dapat dipengaruhi oleh zat pengatur tumbuh, salah satunya adalah sitokinin, yang 
dalam hal ini adalah kinetin. George dan Sherrington, 1984 menyatakan bahwa induksi tunas hanya memerlukan sitokinin dalam konsentrasi tinggi tanpa auksin atau dengan auksin dalam konsentrasi yang rendah.

Mondal et al. (1990), menyatakan bahwa rasio konsentrasi sitokinin dan auksin yang tinggi akan memacu pembentukan tunas. Apabila sitokinin dalam media berada pada jumlah sangat terbatas maka pembelahan sel akan terhambat dan apabila sitokinin dalam media berada dalam jumlah yang cukup, maka pembelahan sel akan lebih cepat.

\subsection{Pertambahan tinggi}

Hasil penelitian respon pertambahan tinggi pucuk anggrek tebu secara in vitro pada umur 1 sampai 8 minggu setelah inokulasi terhadap berbagai konsentrasi kinetin disajikan pada Gambar 1.

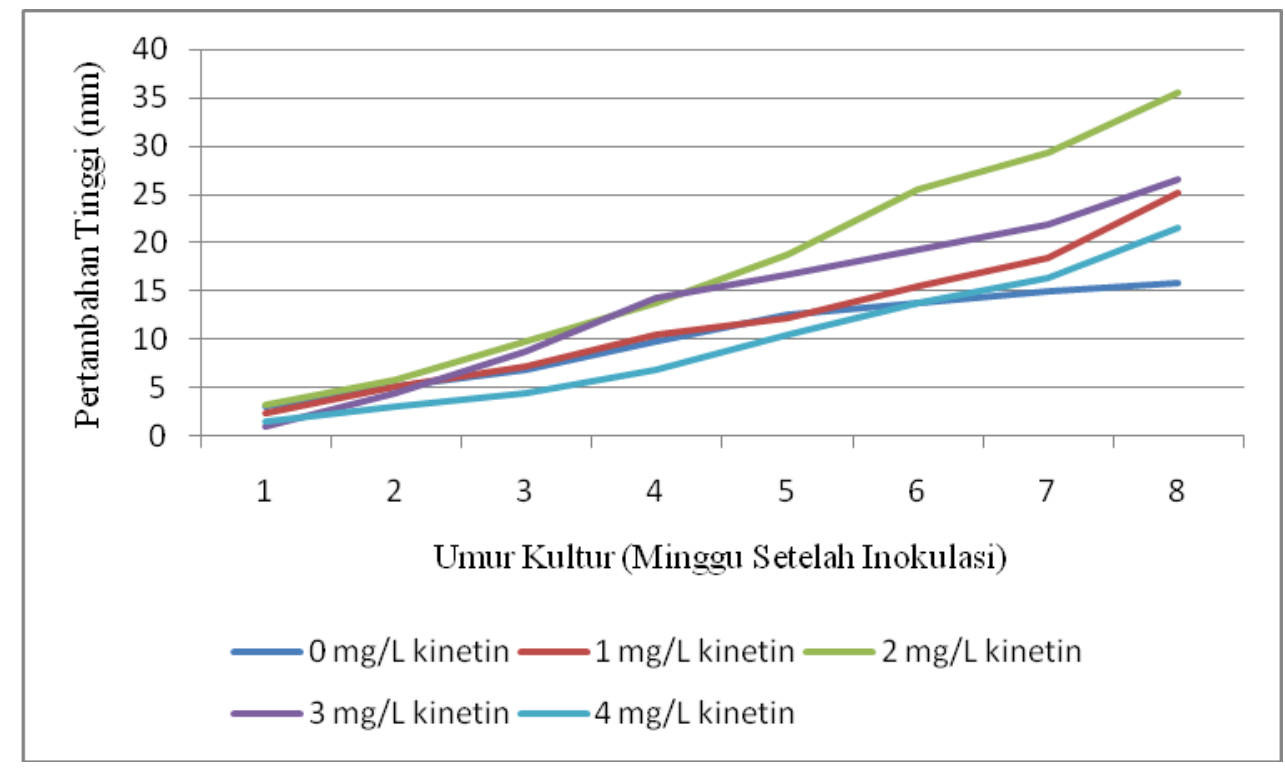

Gambar 1. Pengaruh Konsentrasi Kinetin terhadap Pertambahan Tinggi

Perlakuan konsentrasi kinetin pada awal pertumbuhan belum begitu terlihat, semakin bertambahnya umur kultur semakin nampak bahwa pemberian kinetin pada media memberikan respon lebih baik daripada kontrol (MS tanpa kinetin). Pada kultur umur 8 minggu setelah inokulasi (MSI) terlihat bahwa konsentrasi kinetin $2 \quad \mathrm{mg} . \mathrm{L}^{-1}$ menunjukkan respon pertumbuhan yang terbaik $(35,6 \mathrm{~mm})$ diikuti dengan perlakuan kinetin $3 \mathrm{mg} . \mathrm{L}^{-1}(26,6 \mathrm{~mm})$. Penambahan konsentrasi sebesar 4 mg.L $\mathrm{L}^{-1}$ menghasilkan pertambahan tinggi yang lebih rendah $(21,6 \mathrm{~mm})$ dari pada konsentrasi 1, 2, dan $4 \mathrm{mg} . \mathrm{L}^{-1}$, tetapi masih lebih baik dibandingkan kontrol
$(15,8 \mathrm{~mm}) \quad$ (Gambar 1). Sitokinin diperlukan untuk pembelahan sel atau stimulasi pertumbuhan dan perkembangan tanaman (Bhojwani dan Radzan, 1983). Hasil penelitian menunjukkan bahwa peningkatan konsentrasi kinetin tidak linier dengan pertambahan tinggi, hal tersebut kemungkinan disebabkan kandungan sitokinin alami yang terdapat di dalam eksplan sudah cukup tersedia, sehingga konsentrasi sitokinin eksogen yang diperlukan tidak terlalu besar.

\subsection{Pertambahan diameter batang}

Hasil penelitian respon pertambahan diameter batang pucuk 
anggrek tebu secara in vitro pada umur 1 sampai 8 minggu setelah inokulasi terhadap berbagai konsentrasi kinetin disajikan pada Gambar 2.

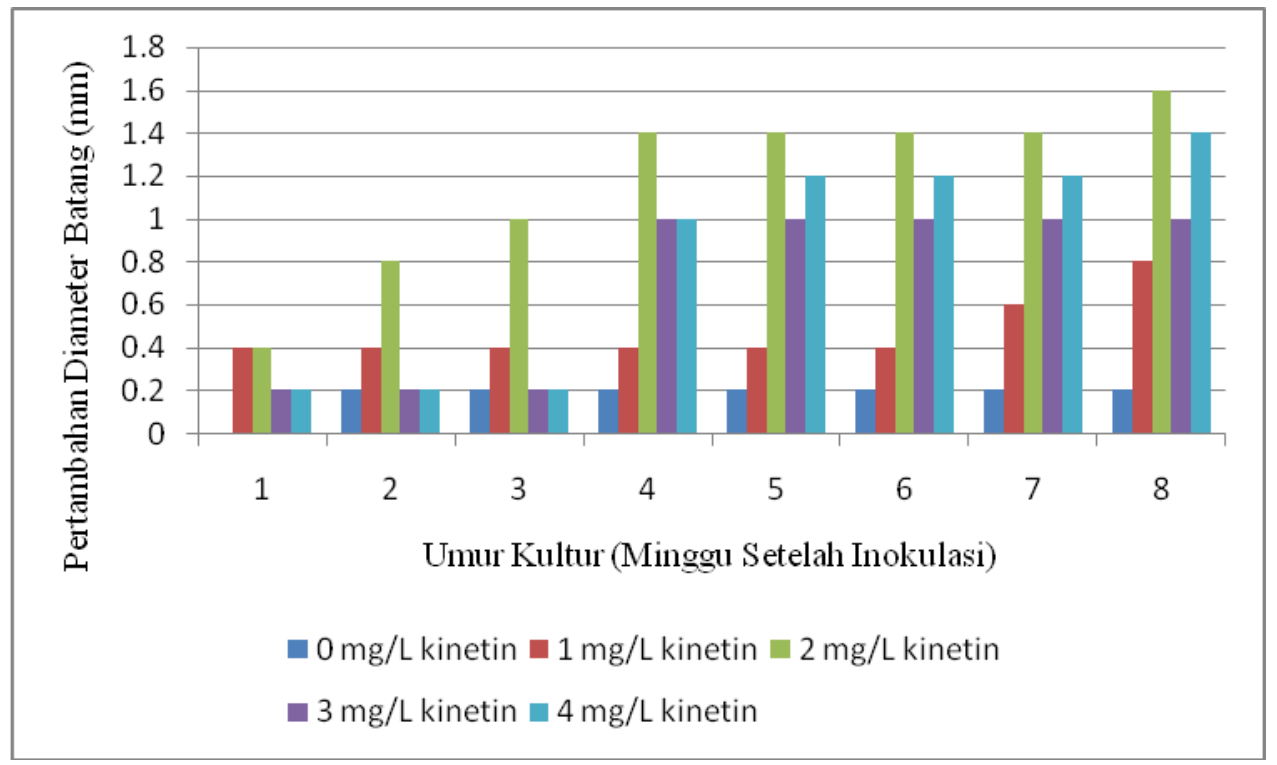

Gambar 2. Pengaruh Konsentrasi Kinetin terhadap Pertambahan Diameter Batang

Pertambahan diameter batang sebesar 0,2-0,4 mm terlihat pada kultur umur satu minggu setelah inokulasi yaitu pada kultur yang diberi perlakuan kinetin (1-4 mg. $\left.\mathrm{L}^{-1}\right)$, sedangkan pada kontrol ( 0 $\mathrm{mg} . \mathrm{L}^{-1}$ kinetin) belum terdapat pertambahan diameter batang. Pertambahan diameter batang baru sebesar $0,2 \mathrm{~mm}$ pada kontrol baru terlihat pada kultur umur 2 minggu setelah inokulasi. Diameter batang pada kontrol tidak terdapat penambahan sampai kultur berumur 8 minggu setelah inokulasi. Penambahan kinetin dengan konsentrasi 1-4 mg.L $\mathrm{L}^{-1}$ mampu meningkatkan pertambahan diameter batang.
Pertambahan terbesar terlihat pada perlakuan $2 \mathrm{mg} . \mathrm{L}^{-1}$ yaitu sebesar $1,4 \mathrm{~mm}$ (umur $4 \mathrm{MSI}$ ) dan 1,6 mm (umur $8 \mathrm{MSI}$ ). Peningkatan konsentrasi kinetin sebesar 4 mg. $L^{-1}$ hanya memberikan pertambahan diameter batang sebesar 1,4 $\mathrm{mm}$ pada kultur umur 8 MSI (Gambar 2).

\subsection{Pertambahan jumlah daun}

Hasil penelitian respon pertambahan jumlah daun pucuk anggrek tebu secara in vitro pada umur 1 sampai 8 minggu setelah inokulasi terhadap berbagai konsentrasi kinetin disajikan pada Gambar 3. 


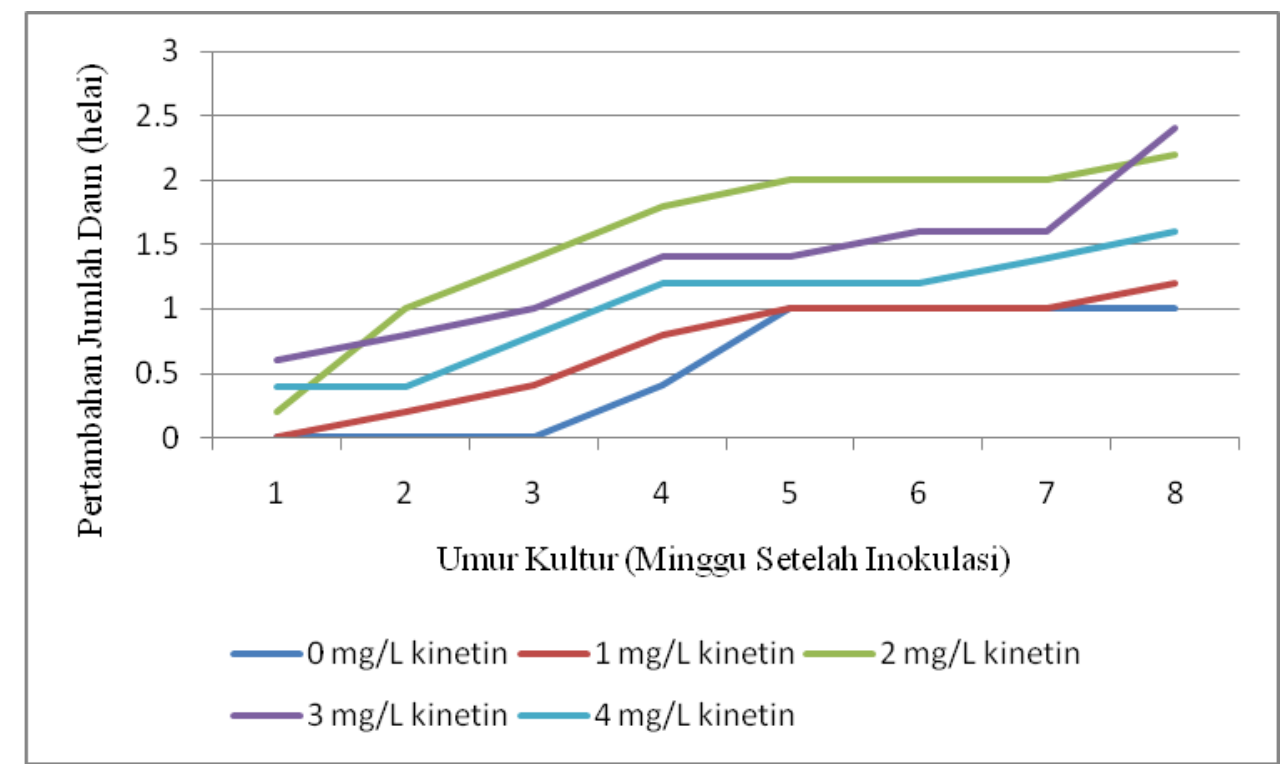

Gambar 3. Pengaruh Konsentrasi Kinetin terhadap Pertambahan Jumlah Daun

Penambahan kinetin pada media tumbuh menunjukkan pertumbuhan daun yang lebih cepat dibandingkan pada kontrol (Gambar 3.). Pertambahan jumlah daun pada media kontrol $\left(\mathrm{MS}_{0}\right)$ baru dimulai pada umur 3 minggu setelah inokulasi. Pada umur 4 MST pertambahan jumlah daun pada media kontrol sebesar 0,4 helai, sedangkan pada media perlakuan pertambahan jumlah daun sudah mencapai 1,8 helai (kinetin 2 $\mathrm{mgL}^{-1}$ ), 1,4 helai (kinetin $3 \mathrm{mgL}^{-1}$ ), 1,2 helai (kinetin $4 \mathrm{mgL}^{-1}$ ), 0,8 helai (kinetin $1 \mathrm{mgL}^{-1}$ ) sedangkan pada umur 8 MSI pertambahan jumlah daun terbanyak sebesar 2,4 helai diperoleh pada media perlakuan kinetin $3 \mathrm{mgL}^{-1}$, selanjutnya berturut-turut sebesar 2,2 helai (kinetin $2 \mathrm{mgL}^{-1}$ ), 1,6 helai (kinetin $4 \mathrm{mgL}^{-1}$ ), 1,2 helai (kinetin 2 $\mathrm{mgL}^{-1}$ ) dan 1,0 helai pada media kontrol

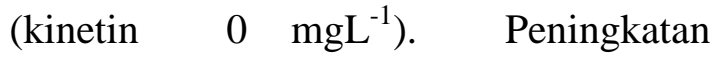
konsentrasi kinetin tidak linier dengan pertambahan jumlah daun. Pertambahan jumlah daun tertinggi pada umur 8 MSI diperoleh pada media MS yg ditambah dengan kinetin $\left.3 \mathrm{mgL}^{-1}\right)$. Menurut Wattimena (1988), variasi respon terhadap pemberian zat pengatur tumbuh dipengaruhi oleh perbedaan fase pertumbuhan, kondisi fisiologis, kemampuan tanaman mengabsorbsi zpt, serta fluktuasi kandungan hormone endogen.

\subsection{Pertambahan lebar daun}

Hasil penelitian respon pertambahan lebar daun pucuk anggrek tebu secara in vitro pada umur 1 sampai 8 minggu setelah inokulasi terhadap berbagai konsentrasi kinetin disajikan pada Gambar 4. 


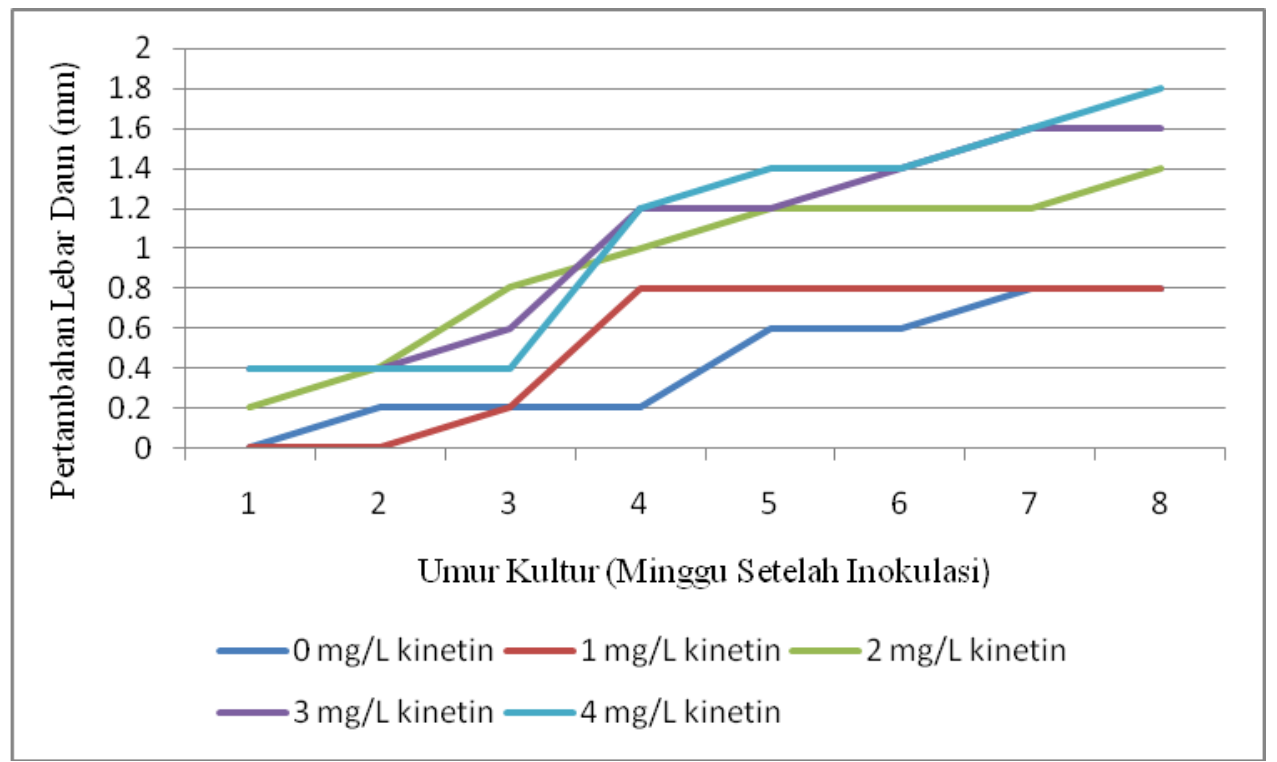

Gambar 4. Pengaruh Konsentrasi Kinetin terhadap Pertambahan Lebar Daun

Peningkatan konsentrasi kinetin yang ditambahkan pada media MS menunjukkan kecenderungan adanya peningkatan lebar daun. Pada umur kultur 4 MSI, pertambahan lebar sebesar $0,2 \mathrm{~mm}$ pada kontrol (kinetin $0 \mathrm{mg} . \mathrm{L}^{-1}$ ), $0,8 \mathrm{~mm}$ (kinetin $1 \mathrm{mg} . \mathrm{L}^{-1}$ ), $1,0 \mathrm{~mm}$ (kinetin $2 \mathrm{mg} . \mathrm{L}^{-1}$ ) , 1,2 mm (kinetin 3 $\mathrm{mgL}^{-1}$ ), dan 1,2 $\mathrm{mm}$ (kinetin $4 \mathrm{mgL}^{-1}$ ). Bertambahnya umur kultur secara umum akan meningkatkan pertambahan lebar daun. Pada kultur umur 8 MSI, pertambahan lebar sebesar $0,8 \mathrm{~mm}$ pada kontrol (kinetin 0 mg. $\mathrm{L}^{-1}$ ), $0,8 \mathrm{~mm}$ (kinetin $1 \mathrm{mg} . \mathrm{L}^{-1}$ ), 1,4 mm (kinetin 2 $\mathrm{mg} . \mathrm{L}^{-1}$ ) , 1,6 mm (kinetin $3 \mathrm{mgL}^{-1}$ ), dan $1,8 \mathrm{~mm}$ (kinetin $4 \mathrm{mgL}^{-1}$ ). Pertambahan lebar daun terbesar didapat pada perlakuan kinetin $4 \mathrm{mgL}^{-1}$ (Gambar 4).

\subsection{Pertambahan panjang daun}

Hasil penelitian respon pertambahan panjang daun pucuk anggrek tebu secara in vitro pada umur 1 sampai 8 minggu setelah inokulasi terhadap berbagai konsentrasi kinetin disajikan pada Gambar 5.
Peningkatan konsentrasi kinetin yang ditambahkan pada media MS tidak selalu menunjukkan adanya peningkatan panjang daun. Peningkatan konsentrasi kinetin sampai $2 \mathrm{mg} . \mathrm{L}^{-1}$ menunjukkan adanya peningkatan panjang daun, selanjutnya peningkatan konsentrasi kinetin akan menurunkan panjang daun pada kultur umur 8 MSI. Pada kultur umur 4 MSI, pertambahan panjang sebesar 8,6 mm pada kontrol (kinetin 0 mg. $\mathrm{L}^{-1}$ ), 7,0 mm (kinetin $1 \mathrm{mg} . \mathrm{L}^{-1}$ ), 10,2 $\mathrm{mm}$ (kinetin $2 \mathrm{mg} . \mathrm{L}^{-1}$ ) , 10,6 mm (kinetin $3 \mathrm{mgL}^{-1}$ ), dan 5,4 mm (kinetin 4 $\left.\mathrm{mgL}^{-1}\right)$. Bertambahnya umur kultur secara umum akan meningkatkan pertambahan panjang daun. Pada kultur umur 8 MSI, pertambahan panjang sebesar 12,2 mm pada kontrol (kinetin 0 mg. $\left.\mathrm{L}^{-1}\right), 13,8 \mathrm{~mm}$ (kinetin $1 \mathrm{mg} . \mathrm{L}^{-1}$ ), 32,6 mm (kinetin $2 \mathrm{mg} . \mathrm{L}^{-1}$ ) , 23,2 mm (kinetin $3 \mathrm{mgL}^{-1}$ ), dan 14,2 $\mathrm{mm}$ (kinetin $4 \mathrm{mgL}^{-1}$ ). Pertambahan panjang daun terbesar didapat pada perlakuan kinetin 2 $\mathrm{mgL}^{-1}$ yaitu sebesar 32,6 mm (Gambar 5). 


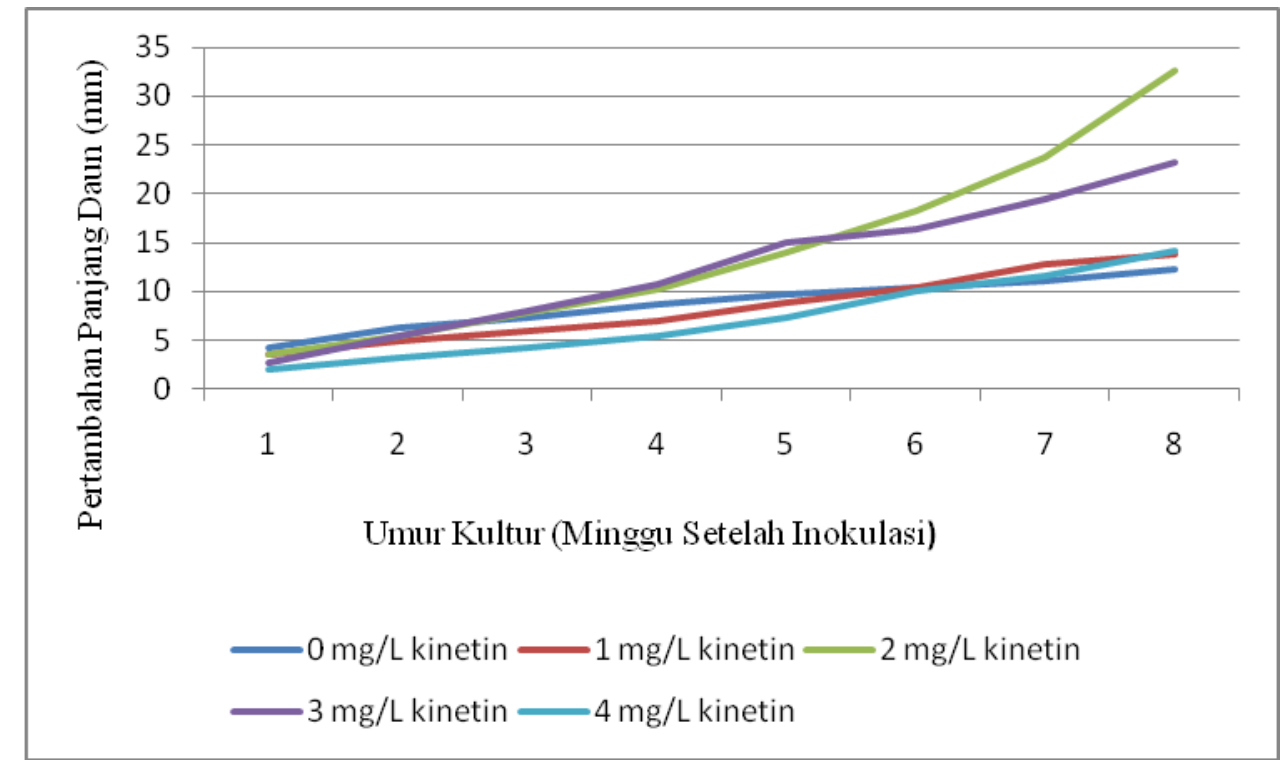

Gambar 5. Pengaruh Konsentrasi Kinetin terhadap Pertambahan Panjang Daun

\subsection{Pertumbuhan akar}

Hasil penelitian respon pertumbuhan akar pucuk anggrek tebu secara in vitro pada umur 8 minggu setelah inokulasi terhadap berbagai konsentrasi kinetin disajikan pada Gambar 6.

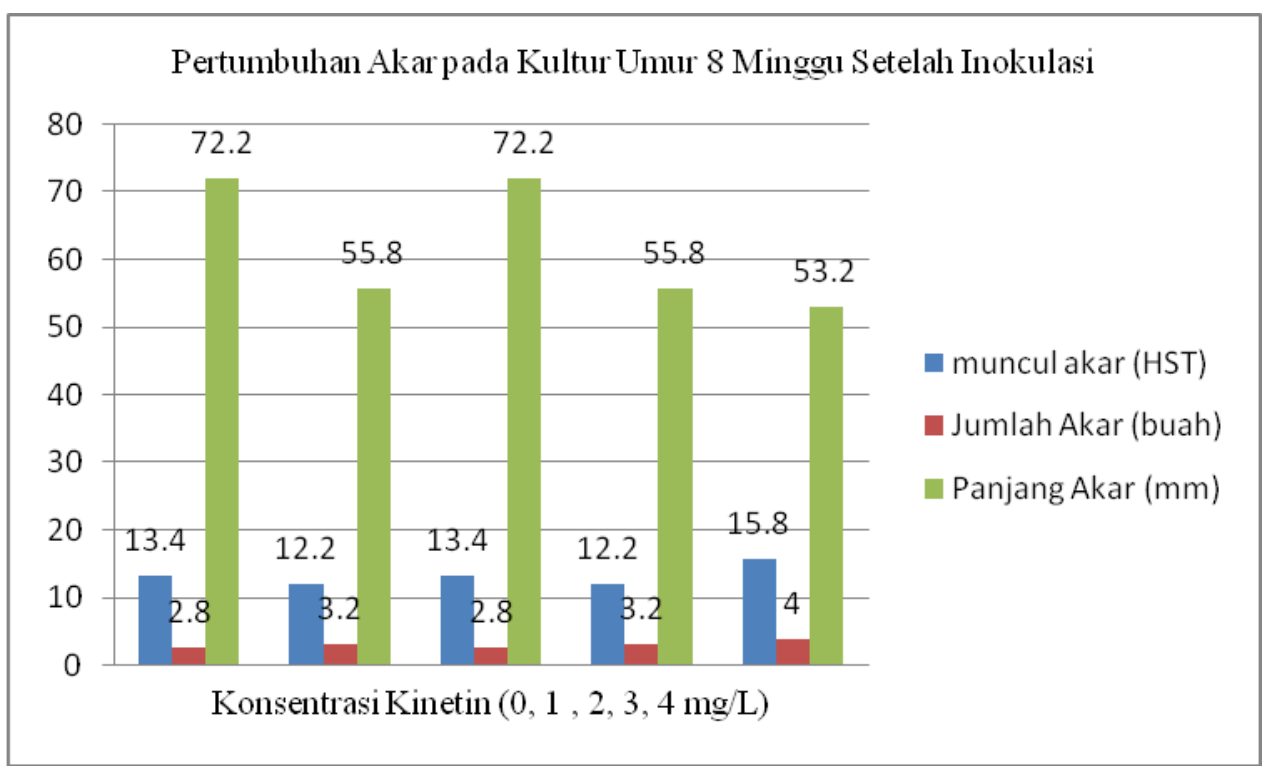

Gambar 6. Pengaruh Konsentrasi Kinetin terhadap Waktu Muncul Akar, Jumlah Akar dan Panjang Akar 
Akar mulai terbentuk pada kultur umur 12,2 hari setelah inokulasi (HSI) pada perlakuan kinetin $1 \mathrm{mg} . \mathrm{L}^{-1}$ dan $3 \mathrm{mg} . \mathrm{L}^{-1}$. Akar juga tumbuh pada media kontrol (kinetin $0 \mathrm{mg} . \mathrm{L}^{-1}$ ) saat kultur berumur 13,4 HIS. Peningkatan konsentrasi kinetin tidak terlalu mempengaruhi waktu munculnya akar. Akar tumbuh pada rentang waktu antara 12-16 HIS, hal tersebut menunjukkan bahwa eksplan pucuk anggrek tebu dapat dengan mudah berakar pada media dasar MS atau media MS ditambah kinetin dengan konsentrasi 1-4 mg. $\mathrm{L}^{-1}$. Penambahan kinetin pada media perlakuan tidak terlalu berpengaruh terhadap waktu terbentuknya akar tetapi memberikan pengaruh terhadap jumlah akar yang terbentuk. Peningkatan konsentrasi kinetin cenderung akan meningkatkan jumlah akar. Jumlah akar terbanyak diperoleh pada perlakuan kinetin 4 mg. $\mathrm{L}^{-1}$ sebanyak 4 buah. Panjang akar terpanjang diperoleh pada perlakuan kontrol dan kinetin $2 \mathrm{mg} . \mathrm{L}^{-1} \quad(72,2 \mathrm{~mm})$, panjang akar terpendek diperoleh pada perlakuan kinetin $4 \mathrm{mg} . \mathrm{L}^{-1}$ (Gambar 6). Peningkatan konsentrasi kinetin cenderung menurunkan panjang akar. Menurut Salisbury dan Ross (1995), konsentrasi zat pengatur tumbuh yang terlalu tinggi akan mendorong sintesis etilen yang selanjutnya akan menghambat pemanjangan akar.

\section{KESIMPULAN}

Penambahan kinetin pada media MS mampu meningkatkan morfogenesis eksplan anggrek tebu yaitu tinggi tanaman, jumlah daun, panjang daun, lebar daun, diameter batang, panjang akar dan jumlah akar. Konsentrasi Kinetin sebesar $2 \mathrm{mg} \mathrm{L}^{-1}$ merupakan konsentrasi terbaik untuk meningkatkan pertumbuhan tinggi, daun dan akar kultur anggrek tebu.

\section{DAFTAR PUSTAKA}

Anonim. (1999). Jenis-jenis Tumbuhan dan Satwa yang Dilindungi. Lampiran Peraturan Pemerintah Republik Indonesia Nomor 7 Tahun 1999 Tanggal 27 Januari 1999.

Anonim. (2015). Pelestarian Grammatophyllum speciosum. Htttp://repisitori umy

Bojwani,S.S., and Radzan. (1983). Plant Tissue Culture: Theory and Practice. New York: Elsivier, Science Publishing Company.

CITES [Convention on International Trade in Endangered Species]. (2005). Checklist of CITES species. https: //cites.org/ eng/resources/pub/ checklist08/ Checklist.pdf

George, E.F., dan Sherrington. (1984). Plant Propagation by Tissue Culture. Handbook and Directory of Directory of Commercial laboratories. Eastern Press. England.

Gunawan, L.W. (1992). Teknik Kultur Jaringan Tumbuhan. Laboratorium Kultur Jaringan Tumbuhan Pusat Antar Universitas (PAU) Bioteknologi IPB, Bogor.

Hartmann, H.T., D.E. Kester, J.R. Davis, dan R.L. Geneve. (1997). Plant Propagation. Prentice-Hall International Inc. New Jersey.

Herawati, W. (2013). Konservasi Anggrek . Purwokerto: Universitas Jenderal Soedirman. http://bio.unsoed.ac.id/sites/default/ files/Konservasi\%20Anggrek.pdf. DiaksesTanggal 19 Februari 2019. 
Irawati. (2001). Tumbuhan langka Indonesia. Pusat Penelitian dan Pengembangan Biologi. LIPI. Balai Penelitian Botani Herbarium Bogoriense. Bogor.

Knudson, L. (1922) Nonsymbiotic Germination of Orchid Seeds. Botanical Gazette, 73, 125. https://doi.org/10.1086/332956

[Citation Time(s): 12 .

Kumaria, S. and Tandon, P. (2010) Biotechnological Approaches to Conservation of Orchids, the Wondrous and Mystic Plants of North-East India. Man and Society: A journal of North East Studies, 4, 61-68. [Citation Time(s):1]

Mondal, M., Gupta, S., Mukherjee, B.B. (1990). In Vitropropagation Of Shoot Buds of Carica papaya L. var. HoneyDew. Plant Cell Rep. 8:609-612.

O'Byrne, P. (1994). Lowland Orchids of Papua New Guinea. SNP Publishers, Singapore.

Pradhan, S., Tiruwa, B.L., Subedee, B.R. and Pant, B. (2016) Efficient Plant Regeneration of Cymbidium aloifolium (L.) Sw., a Threatened Orchid of Nepal through Artificial Seed Technology. American Journal of Plant Sciences, 7, 19641974. https://doi.org/10.4236/ajps.2 016.714179
Sabran, M dan Firmansyah. (2015). Eksplorasi dan Karakterisasi Tanaman Anggrek di Kalimantan Tengah. Buletin Plasma Nutfah: Vol 19 No 1.

Salifah. H.A.B., Muskhazli, M., Rusea, G., Nithiyaa, P. (2011). Variation in mycorrhizal specificity for in vitro symbiotic seed germination of Grammatophyllum speciosum Blume. Sains Malaysiana 40 (5): 451- 455

Salisbury, F. dan Ross, C.W. (1995). Fisiologi Tumbuhan. Bandung. Penerbit ITB Bandung.

Santoso, U., dan F. Nursandi. (2004). Kultur Jaringan Tanaman.Universitas Muhammadiyah Malang: Malang Press.

Satyavathi, V.V., P.P. Jauhar, E.M. Elias, and M.B. Rao. (2004). Genomics, molecular genetic and biotechnology efects of growth regulators on in vitro plant regeneration. Crop Sci. (44): 18391846.

Wattimena, G.A. (1988). Zat Pengatur Tumbuh Tanaman. Laboratorium Kultur Jaringan, PAU Bioteknologi, Bogor. 
Wiendi, N.M.A., G.A. Wattimena dan L.W. Gunawan. (1992). Perbanyakan Tanaman. 12-104. Dalam A.S. Abidin (ed.). Bioteknologi Tanaman. PAU, IPB. Bogor.

Wetherell, DF. (1982). Introduction to In Vitro Propagation Wayne. A very Publishing Group. New Jersey
Yukawa T, Kinoshita A, Tanaka N. (2013). Molecular identification resolves taxonomic confusion in Grammatophyllum speciosum complex (Orchidaceae). Bull Natl Museum Nat Sci 39 (3): 137-145.

Zulkarnain. (2009). Kultur Jaringan Tanaman: Solusi Perbanyakan Tanaman Budidaya. Jakarta: Bumi Aksara. 